\title{
A CASH WAQF INVESTMENT MODEL: AN ALTERNATIVE MODEL FOR FINANCING MICRO-ENTERPRISES IN MALAYSIA
}

\author{
Jarita Duasa ${ }^{1}$ \\ Mohamed Asmy Bin Mohd Thas Thaker ${ }^{2}$
}

\begin{abstract}
This study was designed to empirically determine: (i) to look the factors causes micro enterprises opt for using internal funding instead of external funding; and (ii) to observe the probability of micro enterprises opt for Cash Waqf fund as alternative source of funding their business. The primary data is collected from the administered survey questions in Klang Valley (Selangor and Kuala Lumpur) and the analysis is conducted using statistical analysis and Structural Equation Modeling (SEM). The model is validated its acceptance in the field by adopting the Theory of Reasoned Action (TRA). From the findings, among the factors that lead micro enterprises to use internal funding are strict collateral requirement by commercial financial institutions, high cost of financing, strict documentation requirement and good financial and business track record. Unfortunately, most of them cannot fulfill these conditions and continue to face the problem of accessing finance. The present study has developed the Cash Waqf Investment model to support micro enterprises to improve their access to finance and enhance the skills. Based on the responses received from the field, it has been shown that the intention and readiness of micro enterprises in accepting the model as a source of financial and human capital development services is impressive.
\end{abstract}

Keywords: Micro-enterprises, Financing, Cash waqf, Theory of reasoned action JEL Classification: G1, L3, 014

1 Affiliation and Correspondence: Department of Economics, Faculty of Economics \& Management Sciences, International Islamic University Malaysia, Jalan Gombak, 53100 Kuala Lumpur, M alaysia; Tel: +603-61964790, Email: jarita@iium.edu.my

2 Affiliation: Department of Economics, Faculty of Economics \& Management Sciences, International Islamic University Malaysia, Jalan Gombak, 53100 Kuala Lumpur, Malaysia; Tel: +6012-3904299, Email: asmy@iium.edu.my 


\section{INTRODUCTION}

Micro Enterprises (MEs) in Malaysia becomes as an important engine for economic growth. They account for a substantial share of total SMEs (Small and Medium Enterprises), employment and gross domestic product (GDP). Indeed, they are contributing significantly to the poverty alleviation. In Malaysia, the definition of MEs follows the definition developed by the National SME Development Council (NSDC) based on two criteria, namely full-time employees and annual sales turnover. As shown in Table 1, MEs in Malaysia are defined as the establishment with less than five employees or less than RM 300,000 of the sales turnover for manufacturing sectors and RM 300,000 for other sectors namely agriculture, mining, quarrying, construction and services. How ever, if one of the criteria of MEs either number of employee or annual sales turnover is exceeded the requirement, then the lowest will be given priority.

Table 1.

The Definitions of M icro Enterprises in Malaysia

\begin{tabular}{|c|c|c|}
\hline Type & M anufacturing & $\begin{array}{c}\text { Agriculture, M ining, } \\
\text { Quarrying, Construction } \\
\text { \& Services }\end{array}$ \\
\hline M icro Enterprises & $\begin{array}{l}\text { - Less than } 5 \text { employees } \\
\text { OR } \\
\text { - Less than RM 300,000 }\end{array}$ & $\begin{array}{l}\text { - Less than } 5 \text { employees } \\
\text { OR } \\
\text { - Less than RM } 300,000\end{array}$ \\
\hline
\end{tabular}

Source: Economic Census: Profile of SM Es 2011 \& SM ECorp Press Release, 2013

MEs in Malaysia constitute 77 percent of total SM Es in M alaysia along with small and medium enterprises with 20 percent and 3 percent, respectively (Economic Census: Profile of SMEs, 2011). It forms a largest formation of the enterprises along with small and medium enterprises. Furthermore, among the sectors, the bulk of the services sector is micro establishments, representing over 79.0 per cent of total SMEs. The manufacturing and agriculture sectors also show the same pattern where micro businesses are predominant, accounting for more than half, with 57.1 per cent and 56.3 per cent, respectively. It is followed with the construction sector, where the MEs form about 45 percent (Economic Census: Profile of SMEs, 2011).

In many countries, the MEs sector constitutes the majority of 
the working population. For example, in Latin America Africa, the firms with five or fewer employees account for half of the non-farm workforce and two-thirds of the non-farm workforce in Africa. Meanwhile in Indonesia, firms with five or fewer employees account for almost half of total manufacturing employment followed with in Thailand where the micro firms generate 71 percent of total employment in the trade/service sector (Simmons, 2004). The Consultative Group to Assist the Poor (CGAP) study revealed that through the impact of MEs, it leads to the gains in education, health, and nutrition. For example, In El Salvador, the weekly income of Foundation for International Community Assistance (FINCA) clients increased on average by 145 percent (Simmons, 2004). In India also, half of Society for Helping Awakening Rural Poor through Education (SHARE) clients graduated from poverty. In addition, for the Bangladesh case, nearly all girls in Grameen Bank-client households received schooling, compared to 60 percent of girls in non-client households (Simmons, 2004). M eanwhile, in Vietnam, clients of a Save the Children Partner Organization, reduced food deficits from three months to one (Simmons, 2004).

Despite its importance and the continuous support from the government, MEs in Malaysia are facing some problems. Several studies stated that Malaysian MEs face the problem of accessing finance (Hashim, 1999; Ting, 2004; Saleh \& Ndubisi, 2006; Abdullah \& Mannan, 2010; SME Annual Report, 2011/2012; SME Masterplan, 2012-2020). Many of MEs find difficulties in accessing external financing as they are perceived as a high-risk and a high cost-service market segment (Duc et. al, 2008; Vos et. al, 2007). The requirement of collateral, high cost of financing, difficulty in providing business information, business transaction records and business plans are among the factors that also prevent them from accessing financing (Aris, 2006; Carpenter \& Peterson, 2002).

In view of these, the present study attempts:

1. To discuss the extent of the problems of (i) financing, (ii) human capital (iii) market accessibility (iv) innovation and technology adoption, and (v) infrastructure development faced by MEs in Malaysia.

2. To develop an alternative model that is available for effectively addressing the problems mentioned in (1). 
3. To examine how the factors of attitude and subjective norm of micro entrepreneurs can affect their intention to use the model developed in (2) above.

The remainder of this paper is organized as follows. Section 2 discusses on data collection and methods of analysis. Section 3 discusses on the results and their policy implication. Section 4 then concludes.

\section{LITERATURE REVIEW}

\subsection{Theory}

Theory of Reasoned Action (TRA) is used in this study, which originally proposed by Fishbein and Ajzen (1975) and later revised by Azjen and Fishbein (1980). TRA is a widely used model in the area of social psychology, which is concerned with the determinants of consciously intended behaviours (Razak \& Abduh, 2012). According to Azjen and Fishbein (1980), the TRA model can be expressed as:

$$
B \sim I=(A B) w 1+(S N) w 2
$$

where:

$B \quad$ = behavior

I = the person's intention to perform the behaviour

$A B=$ = the person's attitude toward performing behaviour

$S N \quad=$ subjective norm

$w 1 \& w 2=$ empirically determined weights

This theory basically incorporates measures of attitudes, intention and behaviour. Behaviour is the actual performance of the action that is being measured. The hypothesis is that the best predictor of the behaviour is behavioural intention, which is a person's conscious decision whether to perform a behaviour.

Behavioural intention is predicted by two components which are attitude toward the behaviour and the subjective norm, as shown in Figure 1. Ajzen and Fishbein (1980) describe attitude toward the behaviour as the learned response toward an object or an act, whether it be favourable or unfavourable. 


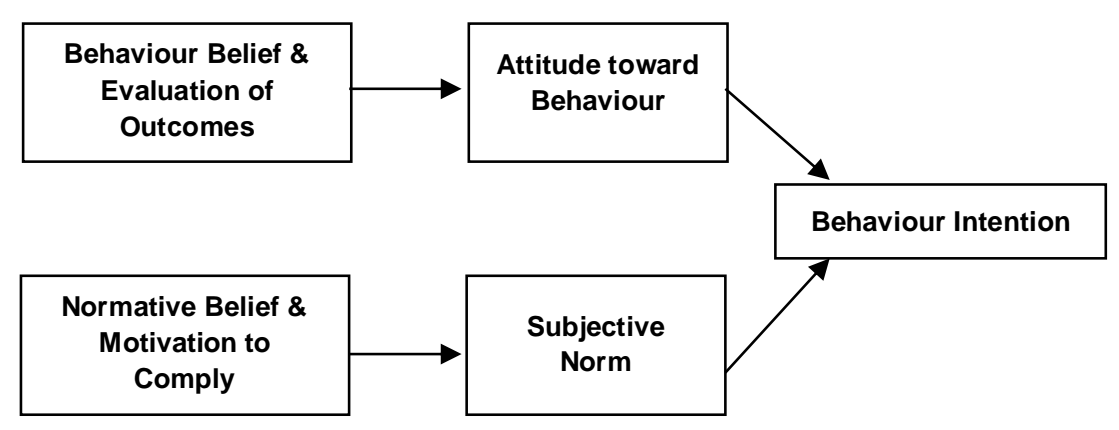

Figure 1.

Model of Theory of Reasoned Action

Source: Azjen \& Fishbein (1980)

The attitude is the sum of the salient belief about the outcomes of performing the behaviour multiplied by the evaluation of whether these outcomes are perceived as favourable or unfavourable. In other words, if the outcome seems beneficial to the individual, he or she may then intend to or actually participate in a particular behaviour.

\subsection{Previous Studies}

Cash Waqf means the devotion of an amount of money by a founder and the dedication of its usufruct in perpetuity to the prescript purposes" (Mohsin, 2008). In this case, the donor endowed Cash Waqf instead of real estate or fixed asset. The use of Cash Waqf comes into the field in eight century after Imam Zufar had approved its use (Toroman et.al, 2007; Cizakza, 2004). Based on his view, Cash Waqf can be invested through partnership basis and the profits generated would be spent for the charity purposes.

Later, in early 15th century these endowments (Cash Waqf) had been approved by the Ottoman courts and they had become the dominant form of Waqf formation and extremely popular till the end of the 16th century (Alias, 2012; Cizakza, 2004). During the Ottoman period, education, public works, health and religious services were financed by Cash Waqf (Toroman et al., 2007). Due to the historical and golden role of Cash Waqf that had played in the past, nowadays in 21st century, there is growing evidence of the revitalization of 
interest, promotion and rethinking on the role of Cash Waqf in community development.

In this revitalization, various suggestions and models of Cash Waqf were initiated by scholars. One of the suggestions that arose is that to integrate Cash Waqf into the enterprises for supporting their financing and human capital development. M any studies have found that Cash Waqf as the most potential source in providing finance and enhance human capital development both in the short and long run. Next section will unveil a number of past studies that attempt to integrate Cash Waqf with financing and human capital development. A good number of studies stressed on the utilization of Cash Waqf for financing for enterprises particularly micro enterprises (Elgari, 2004; Cizakca, 2004; Dusuki, 2008; Hasan, 2010). According to these studies, the proper utilization of Waqf mechanism as a source of financing can play the role in providing sufficient fund to the micro entrepreneurs.

For example, in 2004, Elgari came out with the idea to integrate Waqf into the concept of interest free loan or Qard Hassan. It is to provide as a source of financing for the poor those restricted from accessing into financial institutions. In order to perform this operation, Elgari recommended for establishing a non-profit financial intermediary that is called Q ard Hassan bank. For the capital injection of the bank, it would come from the monetary (cash) Waqf donated by Muslims. However, Elgari restricted his model into Qard Hassan loan for the poor and he does not take into account the issue of permanency that exist within the Qard Hassan loan. The issue of permanence is important as he incorporate Waqf into Qard Hassan loan where the former is characterized by the perpetuity or permanence characteristic. Hence, once he incorporated Waqf into Qard Hassan loan, the permanence of Qard Hassan loan is uncertain (Katsipis, 2013; Central Bank of Bahrain, 2012) as there is tendency of lower repayment or no repayment of the loan from the borrower [poor people]. There is no guarantee to obtain the actual amount of the money that the borrower borrowed. Furthermore, it is also clear that there is no information on how the money obtained from Qard Hassan loan is going to be used by the target group, either for consumption activity or productive activity. 
Cizakza (2004) also suggested a model where the Cash Waqf can be used to meet the social objectives in the society through providing financing assistance for the entrepreneurs through the concept of partnership (Mudharabah). He also suggested that Cash Waqf can be used as microfinance tool to the poor or entrepreneur. However, his model differs from the present study. His model focuses from microfinance perspective and channeled Cash Waqf through intermediary which is micro finance institutions. Furthermore, he limits his model to the Mudharabah arrangement only, where he failed to consider the nature of the Mudharabah contract itself. Usually the contract of Mudharabah involves medium and longer-term project financing and the termination of such partnership contract cannot be done abruptly, and a gradual withdrawal may become necessary (Sadique, 2007). Hence, this contract seems not suitable for micro entrepreneurs, who always looking for short-term financing with small amount of financing. Furthermore, if micro enterprises involve in Mudharabah contract, this contract cannot be re-structured or abrogated without cost and prior to the conclusion of micro enterprises (Bendjilani \& Khan, 1995).The present study focuses specifically on micro enterprises, and directly channel to micro enterprises as source of financing through the Musharakah Mutanaqisah (diminishing partnership) arrangement and Murabahah (short-term) financing arrangement .

Meanwhile, Lahsasna (2010) suggested cash Waqf model to enhance the financial services for SMEs in Malaysia. This suggested model is expected to improve the domestic economic growth and play a vital role in the socioeconomic development by allowing the SM Es to have access to the financial services. The investment of cash Waqf will be made with the debt financing and equity financing contracts such as Murabahah, ljarah, Istisna and Bai Bithamil Ajil, Mudharabah and Musharakah for SMEs in Malaysia. The study by Lahsasna (2010) has some similarities with the present study as both have focused on cash Waqf and enterprises. However, there are also major differences. The present study focuses on component-based SMEs particularly micro enterprises, while Lahsasna's work focused more on SM Es in general.

Also in 2010, Tohirin found that cash Waqf as a solution to lack of access to formal banking institution in Indonesia. Through proper utilization and investment of these cash Waqf assets, SM Es will 
be able to expand their business venture through partnership with cash Waqf institutions. Although the study by Tohirin (2010) has some similarities with the present study as both have focused on cash Waqf and enterprises, yet, there are also major differences. The present study focuses on micro enterprises while Tohirin's work has discussed SMEs in general. Secondly, the present study also tries to integrate cash Waqf into micro enterprises unlike Tohirin's that has treated them as separate entities in partnership.

In addition, Ahmed (2007) proposed Waqf based Islamic microfinance institution model (WIMFI) for channelling funds to facilitate wealth creation for the poor. The WIM FI model constitutes of cash Waqf which become the capital of micro finance institutions. In addition, along with the Waqf endowment donated by the founders, additional Waqf-funds can be generated by issuing Waqf certificates. Later, the Islamic MFI and the client can jointly finance the purchase and selling of a certain good and distribute the profit via various kinds of financing arrangements such as Mudharaba, Musharakah, Murabahah, ljarah, Salam and Istisna. However, his study is more related to the integration of Waqf into Islamic microfinance institution. It differs from the present study where the present study focuses on Cash Waqf and integrating it directly to micro enterprise.

Another important study is by Hassan (2010), who proposed an integrated model of microfinance institutions by combining Zakat and Waqf. He suggested this model with the intention to resolve inadequacy of funds by microfinance institutions. The microfinance institutions may use the Zakat fund to fulfill basic consumption needs and to provide capital investment and/or business initiation fund, while the Waqf funds may be used in providing capital investment and working capital for micro businesses. Such model is able to lead the poor micro-entrepreneurs to be in a better position to focus on their business alone and reduce chances of loan defaults. However, Hassan's model differs from the present study where his model focused more on the issue of inadequacy of fund by micro finance institutions and solving this issue by incorporating Zakat and Waqf. The present study focuses more on micro enterprises and incorporates with Cash Waqf into the model. Furthermore, by integrating Zakat into the model, Hassan failed to acknowledge the issue of where the 
Zakat money must be given to the poor and not loaned to them (Zarqa, 2007).

From these models that have been proposed by various authors, it has been shown the possibility of the integration of Waqf and $\mathrm{M}$ icro enterprises to effectively address the issue of financing for micro entrepreneurs. Although the proposed model by various studies has similarity with the present study, yet, there are also major differences as mentioned earlier. Furthermore, most of the proposed models by (Elgari, 2004; Cizakza, 2004; Ahmed, 2007; Hassan, 2010) are not validated empirically regarding its suitability and acceptability in the market. There are several studies pointed out that the potential of Cash Waqf in uplifting human capital capacity of enterprises (Ahmed, 2004; Tohirin, 2010; A hmed, 2002). These studies also stated that through integrating Waqf for human capital development, it can upgrade, improve and enhance the human capital capacity of enterprises.

\section{METHODOLOGY}

\subsection{Development of Cash Waqf Investment Model}

This section will develop a conceptual model of Cash Waqf Investment Model. This study focuses on Cash Waqf due to its suitability for financing and human capital development especially for micro enterprises. In the present study, it tries to integrate cash Waqf with micro enterprises to support them in terms of source of financing. This model is known as Integrated Cash Waqf Investment Model. The model will be validated its suitability in the market by interviewing the experts from the field and adopting the Theory of Reasoned Action (TRA) which developed by Fishbein and Ajzen (1975).

From previous literature on Cash Waqf, it is claimed that the Cash Waqf can be used to support the financing and human capital development of micro enterprises. Due to this initiative, this research proposes the use of Cash Waqf which later integrated into micro enterprise investment model. It is called Cash Waqf Investment Model as illustrated in Figure 2. This model is proposed as an alternative option for the existing micro enterprises schemes of financing and human capital development in Malaysia. This proposed model aims to 
be a kind of collaborative venture between parties involved. The most important components of this model are the Cash Waqf Institution and micro enterprises.

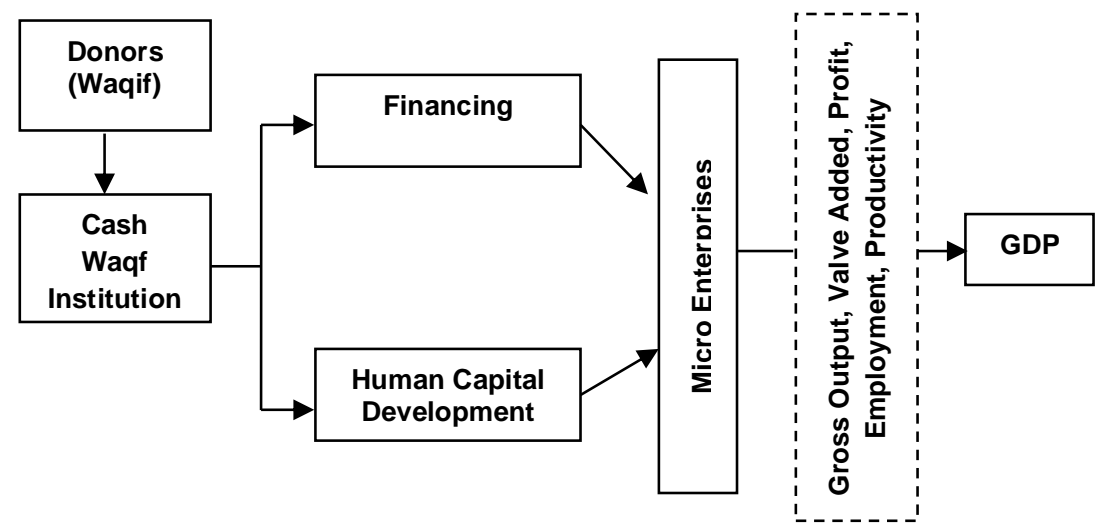

Figure 2.

Integrated Cash Waqf Investment Model

This alternative model should be able to (i) provide financial services and sustainable access to credit at a low cost, taking into consideration the risky nature of the micro enterprises and (ii) provide non-financial services to support human capital development for micro enterprises through providing extensive training and skills development, counselling and education to the micro entrepreneurs with the aim to upgrade and enhance their human capital capacity.

\subsection{Data Collection and Method of Analysis}

For the quantitative method, the primary technique for collecting the quantitative data is utilizing self-developed questionnaire (survey) which containing items of different formats. The formats include dichotomous answers such as "Yes" and "No" and selfassessment items measured by Likert scale. In addition, the demographic questions also will be covered and it will provide information regarding micro entrepreneurs' business profile, gender, education level, income level and employment. This study will focus M Es in the area of Klang Valley (Selangor and Kuala Lumpur). 
The present study's population will consist of MEs in Klang Valley (Selangor \& Kuala Lumpur), M alaysia. This population is chosen mainly because of the database for SMEs including micro enterprises recorded the highest number of such enterprises in the said area. Almost 50 percent of Malaysia SMEs are located in this area. This number of population will be identified from the SMECorp Malaysia, Majlis Amanah Rakyat (MARA), Amanah Ikhtiar Malaysia (AIM) and Tabung Keusahawanan Nasional (TEKUN). The selection of appropriate sample size is important issue in Structural Equation Modeling (SEM). In selecting sample size in SEM, according to Schreiber et al. (2006), the total number of sample size in a study should be followed by the number of its parameters i.e., a minimum of 10 respondents per parameter. Therefore, since this study consisted of 20 parameters which have developed based on Theory of Reasoned Action, the total number of sample are at least 200 respondents. This study also applied most widely used formula by Yamane (1967) and from the calculation the desired sample size required for this study is 398. It is calculated with $95 \%$ confidence level and $5 \%$ error level. Fortunately, in this study, a total of 420 respondents participate in the survey. But only 400 questionnaires i.e. 95.24 percent are usable. The remaining 20 (4.76 percent) questionnaires are not fully completed and excluded from the analysis.

This study adopts a self administered questionnaires design. In the first section of the questionnaire, the questionnaires are developed from the literature review and issues pertaining to finance and human capital development. Later, in section two, the questionnaires are adopted and adapted based on Theory of Reasoned Action (TRA). For TRA questionnaires, this study develops the items in the questionnaires by adapting measures which have been developed by the previous studies that used TRA in their studies (Ajzen \& Fishbein, 1980; Abduh, et al., 2011; Muhammad, 2012). It is to fit the acceptance and intention of micro entrepreneurs in Malaysia to use the Cash Waqf Investment model.

The Confirmatory Factor Analysis (CFA) will be used for acceptable model fit measures: Chi-square, the Goodness of Fit Index (GFI), the Normal Fit Index (NFI), the Comparative Fit Index (CFI) and the Root Mean Square Error of Approximation (RMSEA). The Confirmatory Factor Analysis (CFA) will be utilized as a statistical 
method to determine the relationship between the observed variables and the constructs variables or called latent variables (in our case, the constructs are based on Theory of Reasoned Action) (Byrne, 2001). It is to access the degree in which the result will follow the theory and predict the behavioral intention. As the survey instrument consisted of items from existing scales, the CFA may reduce data dimensionally and create appropriate dimensions for the hypothesized model (Kamil, 2011). Factor loading will be used in this study and be confirmed by acceptable inter-item correlation which for each scale exceeds 0.30 , to meet the minimal level of practical significance as recommended by Robinson et al. (1991). However, this assessment of statistical significance is influenced by the sample size. For example, a sample size with 250 or greater, a factor loading of 3.5 is required for statistical significance purposes based on a 0.05 significance level (Hair et.al, 1995).

In order to estimate the hypothesized model of this study, it employed AMOS version 20 by adopting Maximum Likelihood (ML) estimation. To perform that, this study uses a number of Goodnessof-Fit (GOF) measures which have been developed by researchers to estimate the measure of overall fit. Although many researchers have developed various measures to reflect the model's ability to represent the data, but according to Bryne (2001) and Hair et al. (2010), the measure can be classified into three groups which are (i) absolute measures, (ii) incremental measures, and (iii) parsimony fit measures.

\section{RESULT AND ANALYSIS}

\subsection{Descriptive Analysis}

As depicted in Table 2, 66 percent of the respondents are male while 34 percent are female. Almost three-quarters ( 72 percent) of the respondents are between the age group of 20-40, few are over 40 years of age (28 percent). Consequently, the responses expressed in the survey well reflect the attitudes and perceptions of the middleaged and younger respondents (that is if we consider those above 40 to be the older respondents). Almost 67 percent of the respondents are married. 
Table 2.

Distribution of Respondents by Gender, Age and Marital Status

\begin{tabular}{|l|c|c|c|}
\hline & & Frequency & Percent \\
\hline Gender & M ale & 264 & 66 \\
\hline Age Group & Female & 136 & 34 \\
\hline & $20-30$ & 148 & 37 \\
\hline & $31-40$ & 140 & 35 \\
\hline & $41-50$ & 69 & 17.3 \\
\hline Marital Status & Above 50 & 43 & 10.8 \\
\hline & Single & 117 & 29.3 \\
\hline & M arried & 267 & 66.8 \\
\hline Educational & Divorced & 16 & 4 \\
\hline Level & Primary/Secondary School & 177 & 44.3 \\
\hline & College Diploma/M atriculation & 115 & 28.7 \\
\hline & Bachelor & 83 & 20.7 \\
\hline & Postgraduate (M aster or PhD) & 25 & 6.2 \\
\hline
\end{tabular}

Majority of the respondents (63.3 percent) have been operating their business for $0-5$ years, which can be considered as young firms. About 25.2 percent of the respondents had been in business between 6 to 10 years, which can be considered as middle aged firms. Furthermore, 11.5 percent of the respondent indicates that they had been in business for more than 10 years, which can be considered as older firms. In terms of sectors, majority of the respondents [387 (96.5 percent)] are engaged in the services sector followed by agricultural sector [ 8 ( 2 percent)] as shown in Table 3 . The remaining 4 ( 1 percent) and 2 (0.5 percent) are in manufacturing and construction sectors, respectively. Furthermore, majority of respondents (56.4 percent) are in the RM 10,000-RM 50,000 annual sales turnover group. The remaining 43.6 percent of the surveyed respondents fall in the above RM 50,000 annual sales turnover group. The findings reflect the pattern of annual sales turnover of Malaysian micro enterprises which mainly consist of those with annual earnings between RM 10,000 to RM 50,000 . It is identified that 88.5 percent are having 1-5 employee and 11.5 percent are with 6-10 employee. Majority of the micro enterprises are having the number of employee less than five. 
Most of the respondents used internally generated funding (personal $\&$ family/relative/friend) to start their business. For example, (76.8 percent or 307) used personal saving to commence their business. Meanwhile, 75.3 percent of respondents primarily used financing from family, friends and relatives. Furthermore, 10.7 percent of them had obtained funding from commercial bank while 6 percent get funding from government loan. The remaining 4.7 percent of the respondents indicate that they are being financed by micro finance institutions to start the business. Furthermore, personal savings are often insufficient and lead entrepreneurs to borrow from family, relatives, and friends. Friends and family who are supportive of the business idea provide money either directly to the entrepreneur or into the business. This can be quicker and cheaper to arrange and the repayment terms may be more flexible. A total of 69.7 percent of young firms, 86.1 percent of middle aged firms and 83 percent of older firms borrowed money from family, relatives, and friends to start their business.

The study finds that the most commonly cited reasons for applying external finance: 63 percent (78) of respondents states that the reason is for expansion, 45.5 percent (56) for capital purchases and 33.3 percent (41) for working capital. The remaining 8.1 percent (10) of respondents said they needed finance for relocation. Thus, it reveals that expansion is the most important reason for applying for external finance among the respondents. In enterprises context, expansion can be in terms of expanding the size of the businesses, or increase in the number of branches. Besides, introducing new products is a kind of expansion. It is perhaps true when relating to the respondents of the current study which largely consists of grocery or retail shop, textiles, and kiosk. In order to expand businesses effectively in the market, funding is required by micro enterprises to support it and the findings of this study are consistent with their need of expansion. It reveals that majority of the micro entrepreneurs regardless of their stage of businesses are applying loan for expansion purposes. Expansion of business as mentioned earlier includes expanding the size of the businesses, or increase in the number of branches, and introducing new products.

The respondents were asked about the difficulties in the process of applying and obtaining external finance for the last six 
months to one year. The respondents indicated that they had faced some difficulties in the process of obtaining finance. The respondents mentioned that higher interest rate as one of the difficulties in obtaining external finance for which 73.8 percent of them strongly agreed. This result may be explained by the fact that the financial institutions are charging higher interest rates to micro enterprises in order to compensate for higher costs of information collection, smaller volume of external financing and greater risk of failure. Furthermore, due to the absence of collateral, many financial institutions also respond to this situation by imposing high interest rate in credit market. Several commercial banks such as Agro Bank Malaysia, Maybank Malaysia, Public Bank Malaysia and SME Bank of Malaysia offer micro financing scheme at the rate range from 5 percent to 15 percent while micro finance institutions such as Amanah Ikhtiar Malaysia (AIM) offered financing at 10 percent and TEKUN at 7 percent. Majority of the respondents also agreed that strict documentation requirement and collateral requirement were the obstacles in obtaining external finance. These two factors scored percentage of 76.6 percent and 78.8 percent of respondents agreement, respectively. It seems possible that these results are due to the obligation of the financial institutions to impose several requirements and demand several documentations before granting the loan. It is also to compensate to the nature of micro enterprises that are always perceived as risky businesses. The documents such as business license, business registration, income tax return of the business, (J) Form of proprietor, statement of loans repayment, business and cash flow projection are some of documents that are required by financial institution in Malaysia before granting the loan to the enterprises. 79.8 percent of respondents disclosed that they faced the problem of insufficient amount of financing from financial institutions. The other obstacles, such as long term loan duration (81.3 percent) and characteristics of business ( 82 percent) also can be seen to put undue pressure on a micro enterprise to obtain finance (refer to Table 3). 
Table 3.

Type of Problems during Raising Loan

\begin{tabular}{|c|c|c|c|c|}
\hline \multicolumn{2}{|c|}{} & Yes & No & Total \\
\hline High Interest Rate & $\mathrm{N}$ & 296 & 104 & 400 \\
\cline { 2 - 5 } & $\%$ & 73.8 & 26.2 & \\
\hline \multirow{2}{*}{ Strict Documentation Requirement } & $\mathrm{N}$ & 307 & 93 & 400 \\
\cline { 2 - 5 } & $\%$ & 76.6 & 23.4 & \\
\hline Strict Collateral Requirement & $\mathrm{N}$ & 316 & 84 & 400 \\
\cline { 2 - 5 } & $\%$ & 78.8 & 20.2 & \\
\hline Insufficient Of Amount Of Financing & $\mathrm{N}$ & 320 & 74 & 400 \\
\cline { 2 - 5 } & $\%$ & 79.8 & 20.2 & \\
\hline \multirow{2}{*}{ Long Loan Durations } & $\mathrm{N}$ & 325 & 75 & 400 \\
\cline { 2 - 5 } & $\%$ & 81.3 & 18.7 & \\
\hline Characteristics Of Business & $\mathrm{N}$ & 328 & 72 & 400 \\
\cline { 2 - 5 } & $\%$ & 82 & 18 & \\
\hline
\end{tabular}

M icro enterprises were asked if they are willing to use Cash Waqf Investment model that is developed in the present study as a viable option for financing and human capital development. Out of 400 respondents who answered the question, 324 (76 percent) responded positively while 81 (19 percent) indicate the opposite. This shows that majority of micro enterprises are ready and enthusiastic to use the proposed model to fund their businesses and to enhance their skills development.

From this point, further analysis is conducted using SEM for TRA. The measurement testing model is conducted on the linear function between latent variables and their observed indicators in the model. It is used to establish validity and reliability of variables and their relationship with constructs. Measurement model do not represent any structural relationships or dependences among constructs; all constructs are interdependent and are treated as exogenous variables. In order to performed measurement model validity, there are two components of measurement model validity which are (i) model goodness-of-fit and (ii) construct validity.

\subsection{Full Structural Model Testing}

Once all constructs in the measurement model are validated and fulfilled required fit indices, a structural model can be tested and the 
main analysis using SEM can be carried out. A structural theory depicts conceptual relationship among constructs in the model. The single headed arrow is used to test the causal effects, while the double headed arrow is used to test the correlation effects among constructs as shown in Figure 3 . There are a total of 23 indicators contained in the final structural model. Each indicator is connected to the underlying theoretical construct in a reflective manner. The standardized estimate for the model is presented in Figure 3. The value of coefficient of determination $R^{2}$ is 0.47 . The figure indicates the contribution of exogenous constructs $\mathrm{AT}$ and $\mathrm{SN}$ in estimating the endogenous construct INT is 47 percent. Following the criteria provided by Cohen (1988), the value of $R^{2}$ which is 0.47 is qualified as medium in size because it is bigger than the minimum threshold of $0.10^{3}$.

The absolute fit and incremental fit indices are used for goodness-of-fit test. Behaviour intention (INT) is treated as dependent variable (construct), with which all independents variables (constructs) - attitude toward behaviour (AT) and subjective norm (SN) are supposed to have direct relationship. The output of model fit indices is summarised in the following Table 4.

\section{Table 4.}

Fit Indices for Structural Model

\begin{tabular}{|c|c|c|c|c|}
\hline$\chi^{2}$ & df & Normed $\chi^{2}$ & RM SEA & CFI \\
\hline 867.033 & 208 & 4.168 & 0.089 & 0.936 \\
\hline
\end{tabular}

The absolute fit indices, Normed Chi-Square and RM SEA with respectively values of $4.168(<5)$ and $0.089(<0.1)$ confirm goodnessof-fit of the model. Goodness-of-fit is also verified by the incremental fit index, CFI with value of $0.936(>0.90)$. The statistics are same as those of the best-fit measurement model used for structural model.

3 Cohen (1988) outlined a number of criteria for R2 to gauge the small, medium and larger effect as follows:

$\mathrm{R}^{2}$ : (i) small $\geq 0.10$, (ii) medium $\geq 0.30$, and (iii) large $\geq 0.50$ 
Chisquare $=867.033$

$\mathrm{df}=208$

$\mathrm{P}=.000$

Normed Chisqure $=4.168$

$\mathrm{CFI}=.936$


Figure 3.

Structural Model

There are two main hypotheses is tested in this study. The proposed hypotheses are examined by looking at the significance, signs, and the magnitude of the estimated coefficients (Hair et al. 
2006). Each of the hypotheses listed below is reviewed based on findings relevant to the hypothesis followed by the discussion.

Hypothesis 1: Attitude towards behaviour of micro entrepreneurs is significantly (positively) affecting their intention to use Integrated Cash Waqf Investment Model.

Research hypothesis one is tested using confirmatory factor analysis and structural equation modeling. The result regarding micro entrepreneurs' attitude toward their intention to use Cash Waqf Investment Model is statistically significant $(\beta 1=0.401$, $\mathrm{t}$-value $=$ $6.619, p<0.01$ ) and supporting the research hypothesis as shown in Table 5. The result of standardized coefficient shows that if attitude goes up by 1 standard deviation, behavioural intention goes up by 0.401 standard deviations.

Table 5.

Hypothesis Testing: The Effect of Attitude toward Behaviour on Behavioural Intention of Micro Enterprises

\begin{tabular}{|l|l|c|c|c|c|}
\hline \multicolumn{2}{|c|}{ Hypothesized Path } & $\begin{array}{l}\text { Standardized } \\
\text { Coefficient }\end{array}$ & t-Value & p-Value & Decision \\
\hline Hal & $\begin{array}{l}\text { Attitude toward } \\
\text { behaviour } \\
\text { (AT) } \rightarrow \text { Behaviour } \\
\text { Intention (INT) }\end{array}$ & 0.401 & $6.619^{*}$ & 0.000 & $\begin{array}{c}\text { AT \& INT are } \\
\text { significant and } \\
\text { positively } \\
\text { related }\end{array}$ \\
\hline$* p$-value $<0.01$ & & & \\
\hline
\end{tabular}

Note: Ho: Attitude towards behavior of micro entrepreneurs is not significantly (positively) affecting their intention to use Integrated Cash Waqf Investment Model.

It is asserting that there is a positive relationship between attitudes and intention to use Cash Waqf Investment Model. The attitude of micro entrepreneurs includes positive thinking, risk taking, and other characteristics that affect their intention to use Cash Waqf Investment Model.

Attitudes are an individual's disposition to respond in favor of or against an event. Attitudes could be positive or negative because they are evaluative in nature through indirect measures (Fishbein \& Ajzen, 2010). When the micro entrepreneurs have a more positive view about the outcome of involving in Cash Waqf Investment Model, the more favourable their attitude towards the behavior and 
subsequently, the stronger their intention to take the initiative to use Cash Waqf Investment Model to finance their businesses and also for human capital development. Therefore, attitude strongly predicts behavioural intention of micro entrepreneurs to use Cash Waqf Investment Model. Moreover, the result is not surprisingly as many studies have been found out that attitude was an influential factor for behavioral intentions. This outcome is consistent with the findings from (Ramayah \& Suki, 2006; Brown, 1999). Bentler and Speckarts (1981) examine the theoretical results of adding a direct path between attitude and behavior intention. Their results indicate that direct paths from attitude to actual behavior would improve the predictive power of the model, more so than what had been established by the original TRA model (Fishbein \& Ajzen, 1975). This finding provides insight into the relationship between micro entrepreneurs' attitudes and their intention to use Cash Waqf Investment Model.

Findings also provide an existing Waqf Institutions with a better understanding of micro entrepreneurs' attitudes. Thus, it is important that Waqf institutions find ways to reinforce positive attitudes and build affirmative perceptions of micro enterprises. This can be achieved by (1) promoting the positive images of the role of Integrated Cash Waqf Investment Model in providing financial assistance and human capital development, (2) developing a long-term program with the understanding that attitudes change slowly and require continuous monitor, and (3) providing accurate and clear information about Integrated Cash Waqf Investment Model, thus facilitating participation among micro enterprises. Waqf institutions can also develop ways to target potential micro enterprises that have pre-existing positive attitudes and cultivate them as customers.

Hypothesis 2: Subjective norm of micro entrepreneurs is significantly (positively) affecting their intention to use Integrated Cash Waqf Investment Model.

Confirmatory factor analysis and structural equation modeling are also used to test hypothesis two and found that subjective norms to have a significant influence on micro entrepreneurs' intention to use Cash Waqf Investment Model. Therefore, research hypothesis two is supported ( $\beta 2=0.376$, $\mathrm{t}$-value $=6.773, p<0.01$ ) as shown in Table 6 . The result of standardized coefficient shows that if subjective norm 
goes up by 1 standard deviation, behavioural intention goes up by 0.376 standard deviations.

Table 6.

Hypothesis Testing: The Effect of Subjective Norm on Behavioural Intention of Micro Enterprises

\begin{tabular}{|l|l|c|c|c|c|}
\hline \multicolumn{2}{|c|}{ Hypothesized Path } & $\begin{array}{c}\text { Standardized } \\
\text { Coefficient }\end{array}$ & t-Value & p-Value & Decision \\
\hline Ha2 & $\begin{array}{l}\text { Subjective Norm } \\
\text { (SN) } \rightarrow \text { Behaviour } \\
\text { Intention (INT) }\end{array}$ & 0.376 & $6.773^{*}$ & 0.000 & $\begin{array}{c}\text { SN \& INT are } \\
\text { significant and } \\
\text { positively related }\end{array}$ \\
\hline *p-value <0.01 & & & \\
\hline
\end{tabular}

Note: Ho: Subjective norm of micro entrepreneurs is not significantly (positively) affecting their intention to use Integrated Cash Waqf Investment Model.

It is believed that the social pressure groups that assert subjective norms, including family members, relatives, friends, neighbour and co-workers, influence the decision making process for the survey respondents who are interested in using Cash Waqf Investment Model in the future. This finding is consistent with previous research that social pressure groups have a positive impact and strong influence on behavioural intention (Ramayah \& Suki, 2006; Gopi \& Ramayah, 2007; Cheng et al., 2006). These authors have documented that the TRA's subjective norm construct has positive relationship to that of behavioural intentions.

The outcome of the current study for subjective norm is also similar in the direction. The intention to use Integrated Cash Waqf Investment Model by micro enterprises is influenced by social pressure groups, including family members and friends. Hence, it is recommended that Waqf institutions recognize the power of social pressure groups and develop methods of information dissemination to these groups particularly.

Therefore, Waqf institutions need to find ways to provide and disseminate information about Cash Waqf Investment Model to the social pressure groups of influence (for example, family, friends, and co-workers). For example, Waqf institutions can utilise mass media such as television, radio, newspaper or magazine to provide information about Cash Waqf Investment Model. Furthermore, Waqf institutions can also conduct awareness programmes or campaign to 
the social pressure groups of influence. By providing and disseminating information about Integrated Cash Waqf Investment Model to the social pressure groups of influence, micro enterprises may be more likely to gain support for their intention to use Integrated Cash Waqf Investment Model. This has implications for individuals and potential micro entrepreneurs. Thus, it can be suggested that Waqf institutions has to plan a way on how to develop connection with social groups that relate to micro enterprises including family, friends, and co-workers.

\section{CONCLUSION AND RECOMMENDATION}

\subsection{Conclusion}

Although it can be argued that various financial and human capital development programmes and schemes are provided by government and relevant agencies, numerous issues in relation to access to finance and human capital development appeared. Based on empirical findings, the issues related to accessing finance such as (i) high interest rate, (ii) strict documentation requirement, (iii) strict collateral requirement, (iv) insufficient amount of financing, (v) long loan durations, and (vi) nature of business are affecting the development and contribution of micro enterprises in Malaysia. On the other hand, issues of experience, training and skills are also hampering the human capital development of micro enterprises.

In line with the issues characterising the existing government programmes and schemes, the present study has developed the Cash Waqf Investment model to support micro enterprises to improve their access to finance and enhance the skills. Based on the responses received from the field, it has been shown that the intention and readiness of micro enterprises in accepting the model as a source of financial and human capital development services is impressive.

\subsection{Recommendation}

It is highly suggested that government bodies and other policy makers would be able to develop the proposed model soonest possible as an alternative way of assisting the MEs. For example, the government may provide incentives such as tax exemption of 10 percent (currently in Malaysia, tax exemption of 7 percent is given for 
the donors of Waqf) for the donors of the proposed model as a motivation for them to continuously donate to Cash Waqf fund. By having sustainable Cash Waqf fund from the donors, it would be able to assist micro enterprises by providing financial and human capital development services. Furthermore, the government may encourage the private companies or Government Linked Companies (GLCs) to participate in this model as part of their corporate social responsibility. In this case, the government may also provide incentives such as corporate tax exemption. This is to attract the corporate sector to participate in social-oriented program. 


\section{REFERENCES}

Abduh, M., Duasa, J., \& Omar, M. A. (2011). Factors influence depositors' withdrawal behavior in islamic banks: A theory of reasoned action. World Academy of Science, Engineering and Technology, 60, 2074-2079.

Abdullah, M. A. \& Manan, S. K. A. (2010). Adequacy of financial facilities for small-medium businesses: Empirical findings from Malaysia. International Review of Business Research Papers, 6(4), 535-548.

Ahmed, H. (2002). Financing microenterprises: An analytical study of islamic microfinance institutions. Islamic Economic Studies, Vol.9, No. 2.

Ahmed, H. (2004). Role of zakah and awqaf in poverty alleviation. Jeddah: IRTI/IDB.

Ahmed, H. (2007, March). Waqf-based microfinance: Realizing the social role of islamic finance. Paper presented at the International Seminar on Integrating Awqaf in the Islamic Financial Sector, Singapore, 6-7 M arch 2007.

Ajzen, I., \& Fishbein, M. (1980). Understanding attitudes and predicting social behavior. Englewood Cliffs, NJ: Prentice-Hall.

Alias, T. A. (2012). Venture capital strategies in waqf fund investment and spending. ISRA International Journal of Islamic Finance, $4(1)$.

Aris, N. M. (2006, September). SMES: Building blocks for economic growth. Paper Presented at National Statistics Conference, Department of Statistics, M alaysia, 4-5 September 2006.

Bendjilali, B. \& Khan, T. (1995). Economics of diminishing musharakah (Research Paper No.31). Jeddah: Islamic Research and Training Institute (IRTI).

Bentler, P. M., \& Speckart, G. (1981). Attitudes cause behaviour: A structural equation analysis. Journal of Personality and Social Psychology, 40(2), 226-238.

Brown, S. (1999). Public attitudes toward the treatment of sex 
offenders. Legal and Criminological Psychology, 4, 239-252.

Byrne, B. M. (2001). Structural equation modeling with AM OS: Basic concepts, applications, and programming. New York, NY: Taylor \& Francis Group.

Carpenter, R. E., \& Petersen, B. C., (2002). Is the growth of small firms constrained by internal finance?. The Review of Economics and Statistics, MIT Press, 84(2), 298-309.

Central Bank of Bahrain (CBB) (2012). The review, March 2012. Bahrain.

Cheng, S., Lam, T., \& Hsu, C. H. C. (2006). Negative word-of-mouth communication intention: An application of the theory of planned behavior. Journal of Hospitality and Tourism Research, 30(1), 95-116.

Cohen, J. (1988). Statistical power analysis for the behavioral sciences. New Jersey: Lawrence Erlbaum Associates.

Cizakca, M. (2004, March). Cash waqf as alternative to NBFls bank. Paper presented at The International Seminar on Nonbank Financial Institutions: Islamic Alternatives, Kuala Lumpur, 1-3 March 2004.

Department of Statistics. (2011). Economic census: Profile of SMES. Malaysia: Author.

Duc, D. S., Marriott, N., \& Marriott, P (2008). The bank's uses of smaller companies' financial information in the emerging economy of Vietnam: A user's oriented model, corporate governance in less developed and emerging economies. Research in Accounting in Emerging Economies, 8, 519-548.

Dusuki, A. W. (2008). Banking for the poor: The role of islamic banking in microfinance initiatives. Humanomics, 24(1), 49-66.

El-Gari, M. A. (2004, March). The qard hassan bank. Paper presented at The International Seminar on Nonbank Financial Institutions: Islamic Alternatives, Kuala Lumpur, 1-3 M arch 2004.

Fishbein, M., \& Ajzen, I. (1975). Belief, attitude, intention, and behavior: An introduction to theory and research. Reading, MA: Addison-Wesley. 
Fishbein, M., \& Ajzen, I. (2010). Predicting and changing behavior: The reasoned action approach. New York: Psychology Press (Taylor and Francis).

Gopi, M., \& Ramayah, T. (2007). Applicability of theory of planned behavior in predicting intention to trade online: Some evidence from a developing country. International Journal of Emerging Markets, 2(4): 348-360.

Hair, J. F., et al. (1995). Multivariate data analysis (fourth edition). Upper Saddle River, New Jersey: Prentice Hall.

Hair, J. F., et al. (2006). Multivariate data analysis (sixth edition). Upper Saddle River, New Jersey: Pearson Prentice-Hall.

Hair, J. F., Black, W. C., \& Babin, B. J. (2010). Multivariate data analysis: A global perspective. New Jersey: Pearson Education.

Hassan, M. K. (2010, January). An integrated poverty alleviation model combining zakat, awqaf and microfinance. Paper presented at $7^{\text {th }}$ International Conference - The Tawhidi Epistemology: Zakat And Waqf Economy, Bangi, Selangor, 2010.

Hashim, M. K. (1999). A review of the role of SMEs in the manufacturing sector in Malaysia. Malaysian Management Review, 40-49.

Kamil, N. M. (2011). Organizational citizenship behavior from islamic perspective and the role of taqwa: Empirical analysis of business organizations In Malaysia (Unpublished PhD Thesis). International Islamic University M alaysia (IIUM ).

Katsipis, V. (2013). Takaful review. Dubai: A.M Best Company.

Lahsasna, A. (2010, January). The role of cash-waqf in financing micro and medium-sized enterprises. Paper presented at $7^{\text {th }}$ International Conference-The Tawhidi Epistemology: Zakat and Waqf Economy, Bangi, Selangor, 2010.

Muhammad, A. D. (2012). Challenges of micro finance and prospect of introducing and developing IMIM in Nigeria (Unpublished PhD Thesis). International Islamic University Malaysia (IIUM).

Mohsin, M. I. A. (2008, July). Cash waqf a new financial product model aspects of shariah principles on ITS commercialization. 
Paper presented at Islamic Banking, Accounting and Finance Conference (iBAF 2008), organized by Faculty of Economics and Muamalat, Universiti Sains Islam M alaysia, Kuala Lumpur, 28-29 July 2008.

Razak, D. A., \& Abduh, M. (2012). Customers' attitude towards diminishing partnership home financing in islamic banking. American Journal of Applied Sciences, 9(4), 593-599.

Ramayah, T., \& Suki N. M. (2006). Intention to use mobile PC among MBA students: implications for technology integration in the learning curriculum. UNITAR e-Journal, 2(2).

Robinson J. P., Shaver, P. R., \& Wrightsman, L. S. (1991). Measures of personality and social psychological attitudes. San Diego: Academic Press.

Schreiber, J. B., et al. (2006). Reporting structural equation modeling and confirmatory factor analysis results: A review. The Journal of Educational Research, 99(6), 323-337.

Sadique, M. A. (2007, April). Financing micro and medium sized enterprises through decreasing partnership (musharakah mutanaqisah): Refining shari'ah and banking aspects for enhanced applicability. Paper presented at First International Islamic Conference on Inclusive Islamic Financial Sector Development: Enhancing Islamic Financial Services for M icro and Medium Sized Enterprises (M M SE), Jeddah, 17-19 A pril 2007.

Saleh, A. S., \& Ndubisi, N. O. (2006). An Evaluation of SME development in Malaysia. International Review of Business Research Paper, 2(1), 1-14.

Simmons, E. (2004). The role of microenterprise assistance in U.S. development policy. Economic Perspectives, An Electronic Journal of the U.S. Department of State, 9(1), 6-9.

National SME Development Council. SME annual report 2011/2012: Redefining the Future. Malaysia: Author.

SME Corp. Malaysia. (2013). Guideline for new SME definition. Kuala Lumpur: Author. 
SME Corp. Malaysia. (2012). SME masterplan 2012-2020: Catalyzing growth and income. Kuala Lumpur: Author.

Ting, 0. K. (2004). SMEs in Malaysia: Pivotal points for change. Retrieved October 1, 2015, from http://www/mca.org.my.

Toraman, C., Tuncsiper, B., \& Yilmaz, S. (2007, August). Cash awqaf in the ottomans as philanthropic foundations and their accounting practices. Paper presented at The Fifth Accounting History International Conference, Banff, Canada.

Tohirin, A. (2010, January). The cash waqf for empowering the small businesses. Paper presented at $7^{\text {th }}$ International Conference-The Tawhidi Epistemology: Zakat And Waqf Economy, Bangi, Selangor, 2010.

Vos, E., Yeh, A. J. Y., Carter, S., \& Tagg, S. (2007). The happy story of small business financing. Journal of Banking and Finance, 31(9), 2648-2672.

Yamane, T. (1967). Statistics, An introductory analysis ( $2^{\text {nd }}$ ed.). New York: Harper and Row.

Zarqa, M. A. (2007, April). Leveraging philanthropy: Monetary waqf for micro finance. Paper presented at Symposium Towards An Islamic M icro-Finance, Harvard Law School, 14 A pril 2007. 